уДК 681.62:655.344

( С. М. Зигуля, к.т.н., доцент, КПІ ім. Ігоря Сікорського, Київ, Україна

\title{
ДОСЛІДЖЕННЯ ПАРАМЕТРІВ ЯКОСТІ \\ ДРУКОВАНОГО ВІДБИТКА ПРИ ДВОБІЧНОМУ ДРУКУВАННІ НА АРКУШЕВИХ ОФСЕТНИХ МАШИНАХ
}

\author{
Досліджено параметри якості друкованого відбитка \\ при двобічному друкуванні на аркушевих офсетних машинах. \\ Встановлено взаємозв'язок між обробкою поверхні \\ друкарського циліндра і параметрами якості друкованого \\ відбитка.
}

\begin{abstract}
Ключові слова: офсетна аркушева машина; двобічне друкування; друкарський циліндр; оздоблювально-зміцнювальна обробка; оптична густина; розтискування крапки.
\end{abstract}

\section{Постановка проблеми}

Підвищення ефективності роботи аркушевих офсетних машин досягається за рахунок використання пристроїв перевертання аркушів. На таких машинах аркуш задруковується з одного боку, потім поступає на пристрій для перевертання, перевертається, після чого задруковується 3 іншого боку. Таке обладнання має низку переваг: скорочується технологічний час для друкування, збільшується продуктивність тощо. З підвищенням технічного рівня поліграфічного обладнання зростають вимоги до якості відбитків. Якість друкованого відбитка задається відповідно до технологічних умов виготовлення поліграфічної продукції та її експлуатації. Серед проблем, які виникають при двосторонньому друкуванні, - несуміщення фарби на відбитках, неспівпадання лицьового боку зі зворотнім, розтискування крапки, деформація аркуша паперу, забруднення фарбою відбитка $[1,2]$. Причинами можуть стати багато факторів, зокрема властивості поліграфічних матеріалів, технологічні режими процесу друкування, конструкція обладнання, умови праці [3]. Розглядаючи кожен з факторів, варто виділити конструкцію аркушевої машини, а саме друкарський циліндр, на який, при перевертанні, монтують металеву пластину для захисту віддрукованого зображення. Втрата працездатності та прискорений вихід з ладу під час експлуатації $€$ наслідком процесів, які відбуваються у приповерхневих шарах деталей, а саме: тертя та зношування, перерозподіл залишкових напружень та їх надмірна концентрація, розвиток мікротріщин, знеміцнення.

У зв'язку з цим актуальним $€$ аналіз досліджень параметрів

(C) $2017 \mathrm{p}$. 
друкарського відбитка з урахуванням обробки поверхні друкарського циліндра методом поверхнево-пластичного деформування.

\section{Аналіз попередніх досліджень}

Уся історія розвитку поліграфії безпосередньо пов'язана з вирішенням питання вдосконалення якості друку, ідентичності відбитків за кольором і графічною точністю. Незважаючи на велику кількість досліджень, на сьогодні не вдалося виявити загальновизнаних чітких залежностей між технологічним процесом обробки поверхні друкарського циліндра та якістю відбитка.

У літературних джерелах [4, 5] якість поліграфічної продукції оцінюють залежно від іï̈ призначення. На цьому принципі формуються показники якості в нормативній документації і подаються певні рекомендації для виготовлення поліграфічної продукції. Рівень якості конкретного виду друкованої продукції залежить від повноти врахованих характеристик та їх аналізу [6].

Встановлено, що якість друкованого відбитка характеризується системою показників, кожен з яких задається виходячи з технологічних умов виготовлення видання та його експлуатації. Дотримання показників якості в процесі друкування залежить від властивостей паперу, фарб, зволожувального розчину, гумовотканинного полотна, друкарської форми, противідмарювальної металевої пластини, а також від технологічних режимів аркушевих машин.
Відхилення від умов будь-якого елемента системи призводить до погіршення показників якості поліграфічної продукції $[7,8]$.

Систематизувати взаємодію в процесі друкування паперу $\rightarrow$ фарби $\rightarrow$ зволожувального розчину $\rightarrow$ друкарської форми $\rightarrow$ друкарської машини $\rightarrow$ противідмарювальної металевої пластини тощо, потрібно в об'єднанні всіх етапів: від проектування та виготовлення деталей поліграфічних машин до виконання ними своїх функціональних можливостей - стабільного перебігу друкарського процесу i виготовлення якісної поліграфічної продукції.

\section{Мета роботи}

Аналіз досліджень параметрів якості друкованого відбитка, а саме параметрів оптичної густини, розтискування крапки при двобічному друкуванні на аркушевих офсетних машинах 3 урахуванням обробки друкарського циліндра методом вібраційного накатування.

\section{Результати проведених досліджень}

Умови роботи контактувальної пари при двобічному друкуванні $€$ досить складними. По-перше, висока швидкість обертання, великі навантаження, а по-друге агресивне середовище. На друкарський циліндр при двобічному друкуванні монтують металеву пластину для відмарювання фарби, віддрукованої на звороті. Через нещільне прилягання металевої пластини до поверхні друкарського циліндра можливе потрапляння фарби, зволожувального розчину, паперового 
пилу на його поверхню. Це призводить до пошкодження поверхні циліндра: утворення мікротріщин, викришування, абразивного та окислювального зношування. Це вкрай негативне явище, оскільки відновлення поверхні друкарського циліндра досить складний працемісткий і дорогий процес.

Якість поверхні друкарського циліндра разом з противідмарювальною пластиною впливає на якісні показники відбитка при двобічному друкуванні поліграфічної продукції. Тому досить важливо було визначити вплив комплексного технологічного процесу, а саме обробку поверхні друкарського циліндра методом вібраційного накатування і подальшим його хромуванням на параметри якості відбитка.

На рис. 1-3 представлені результати вимірювань $\mathrm{D}_{\text {опт }}$ отриманих при друкуванні на різних видах паперу.

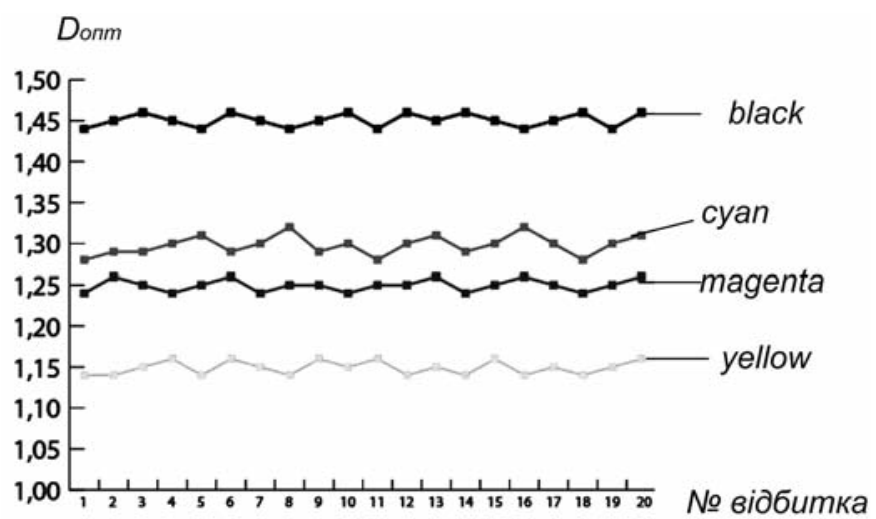

Рис. 1. Оптична густина відбитка на крейдованому глянцевому папері Blu Star Gloss масою 1 м² $^{2} 120$ г

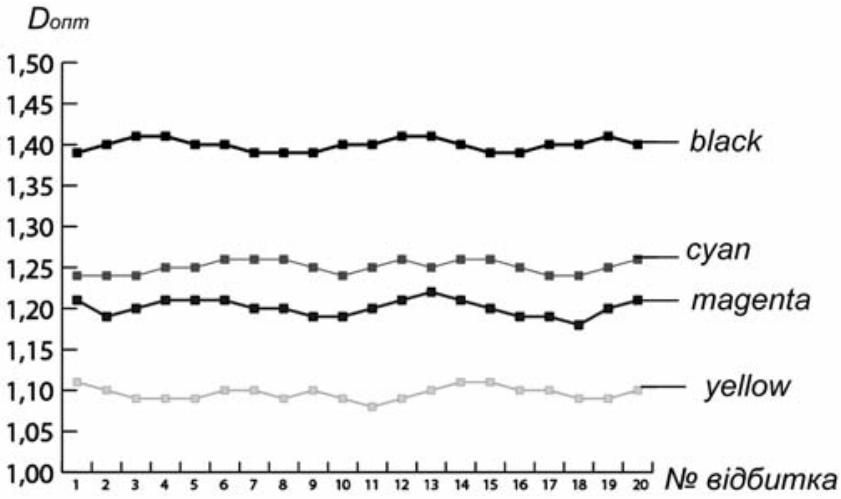

Рис. 2. Оптична густина відбитка на крейдованому матовому папері Arctic масою $1 \mathrm{~m}^{2} 130$ г 
На рис. 1-3 простежується рівномірний розподіл показників оптичної густини, що підтверджує достатньо високе підтримання якості відбитка. Відхи-

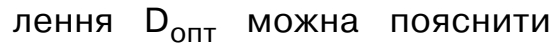
впливом маси, рівномірності за товщиною, структурою паперу та властивостями фарби.

Для порівняння показників якості отриманих на відбитках з нормативними показниками було проведено математичні розрахунки визначення середніх значень показників, їх стандартних відхилень, розкид та його процентне співвідношення до нормативних показників [9].

Розрахунок середнього значення оптичної густини проводився за формулою

$$
\bar{x}=\frac{x_{1}+x_{2}+\ldots+x_{n}}{n},
$$

де $x$ - значення вибірки; $n$ кількість вибірок.

Стандартне відхилення обчислювалося за формулою

$$
S=\sqrt{\frac{\sum(x-\bar{x})^{2}}{(n-1)}},
$$

де $\bar{X}$ - середнє значення вибірки.

Розрахунок розкиду проводився за формулою:

$$
\mathrm{R}=\mathrm{x}_{\max }-\mathrm{x}_{\min },
$$

де $x_{\max }-$ найбільше значення у вибірці; $x_{\min }$ - найменше значення у вибірці.

Дані розрахунків занесені в табл. 1.

Показники наведені в табл. 1, показують що стандартні відхилення у процентному відношенні до нормативних показників оптичної густини (близьких за значеннями до норм ISO 12647-2) перебували в інтервалі від 0,3 \% до 4 \% залежно від виду паперу, а відношення розкиду до середніх значень - від 1,4 \% до 3 \%.

При оцінюванні кольорового зображення з урахуванням властивостей матеріалів розтискування крапки $є$ основною величиною для кількісної характеристики відбитка. Розтискування крапки полягає у збільшенні розмірів штрихових і растрових елементів на відбитку в процесі друкування і призводить до значного колірного і градаційного спотворень.

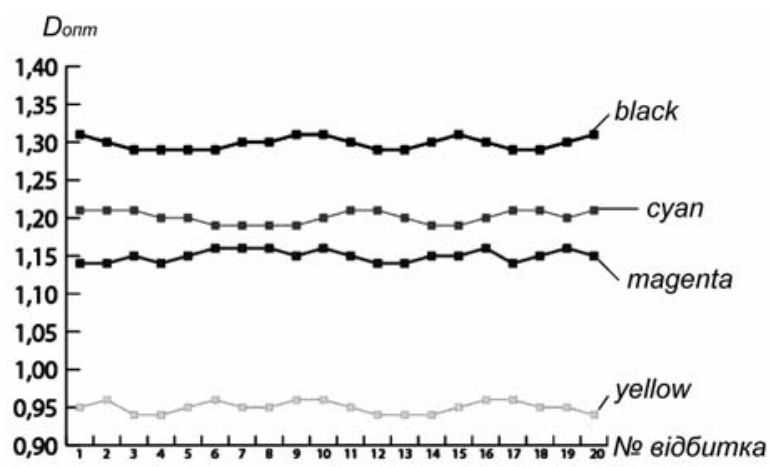

Рис. 3. Оптична густина відбитка на офсетному папері Lumiset масою 1 м² $^{2} 0$ г 
На збільшення розміру растрового елемента впливають як оптичні так і механічні фактори. Причиною оптичного розтискування $€$ розсіювання світла в товщі паперу. Світло, що проникає через незадруковану поверхню паперу, розсіюється і набуває кольору фарби, через яку воно проходить. У результаті виникає приріст розміру растрового елемента і збільшення оптичної густини. Оптичне розтискування можна компенсувати на етапі додрукарської під- готовки, застосовуючи градаційну корекцію зображення.

Механічне розтискування $\epsilon$ наслідком виходу фарби за межі друкувальних елементів. На величину механічного розтискування впливають такі фактори: тиск у друкарському процесі; в'язкість фарби; кількість фарби, яка переноситься на задруковуваний матеріал; характеристики поверхні задруковуваного матеріалу.

На рис. 4-9 представлено результати вимірювань розтискування крапки на полях із коефіцієнтом

Таблиця 1

Математично-статистичні розрахунки показників оптичної густини

\begin{tabular}{|c|c|c|c|c|c|}
\hline \multirow[b]{2}{*}{ Фарба } & \multicolumn{5}{|c|}{ Оптична густина } \\
\hline & $\begin{array}{c}\text { Середнє } \\
\text { значення, } \\
\bar{X}\end{array}$ & $\begin{array}{c}\text { Стандартне } \\
\text { відхилення, } \\
\text { S }\end{array}$ & $\begin{array}{c}\text { Розкид, } \\
\text { R }\end{array}$ & \begin{tabular}{|c|} 
Відношення \\
стандартного \\
відхилення \\
до нормо- \\
ваного \\
показника
\end{tabular} & $\begin{array}{c}\text { Відношення } \\
\text { розкиду до } \\
\text { стандартного } \\
\text { показника }\end{array}$ \\
\hline \multicolumn{6}{|c|}{ Крейдований глянцевий папір Blu Star Gloss масою 1 м² 120 г } \\
\hline Cyan & 1,3 & 0,012 & 0,04 & 0,92 & 3,07 \\
\hline Magenta & 1,2 & 0,051 & 0,02 & 4,08 & 1,6 \\
\hline Yellow & 1,15 & 0,008 & 0,02 & 0,7 & 1,7 \\
\hline Black & 1,45 & 0,01 & 0,02 & 0,69 & 1,4 \\
\hline \multicolumn{6}{|c|}{ Крейдований матовий папір Arctic масою 1 м² 130 г } \\
\hline Cyan & 1,25 & 0,026 & 0,02 & 2,08 & 1,6 \\
\hline Magenta & 1,2 & 0,009 & 0,03 & 0,75 & 2,5 \\
\hline Yellow & 1,4 & 0,004 & 0,03 & 0,37 & 2,14 \\
\hline Black & 1,4 & 0,008 & 0,02 & 0,57 & 1,4 \\
\hline \multicolumn{6}{|c|}{ Офсетнй папір Lumiset масою 1 м² 80 г } \\
\hline Cyan & 1,3 & 0,01 & 0,03 & 0,7 & 2,3 \\
\hline Magenta & 1,25 & 0,008 & 0,02 & 0,64 & 1,6 \\
\hline Yellow & 1,15 & 0,008 & 0,02 & 0,69 & 1,7 \\
\hline Black & 1,45 & 0,008 & 0,02 & 0,55 & 1,4 \\
\hline
\end{tabular}




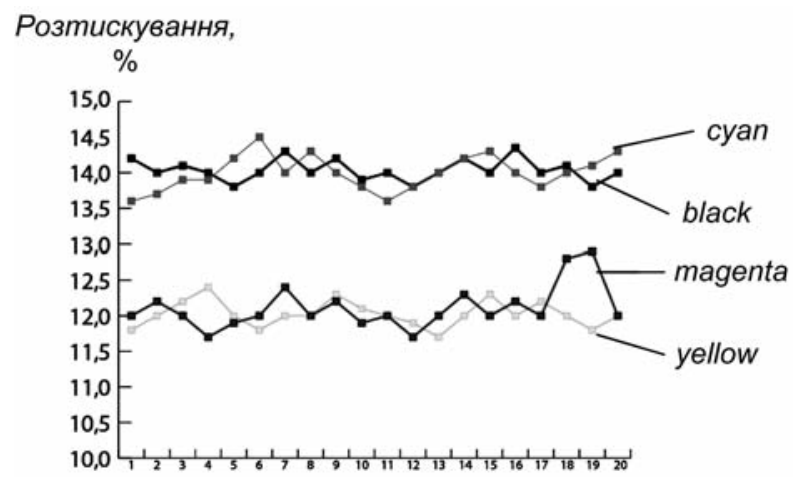

Рис. 4. Розтискування крапки на крейдованому глянцевому папері Blu Star Gloss масою 1 м² 120 г, поле 40 \%

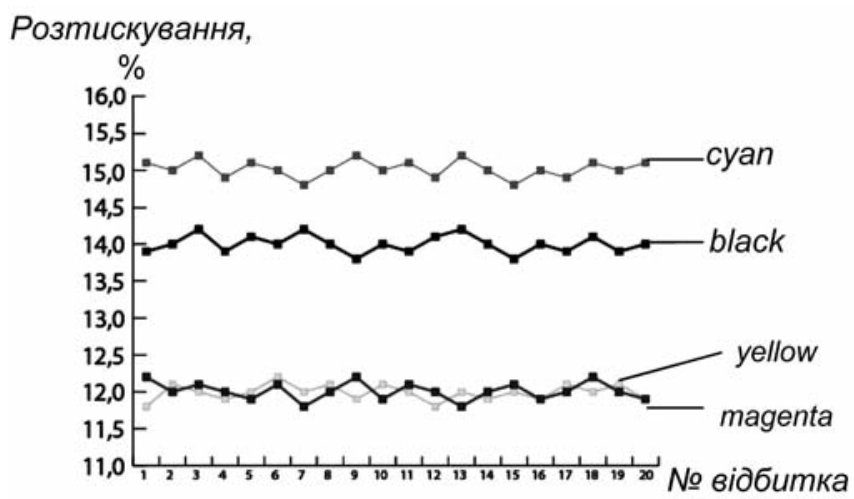

Рис. 5. Розтискування крапки на крейдованому матовому папері

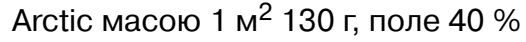

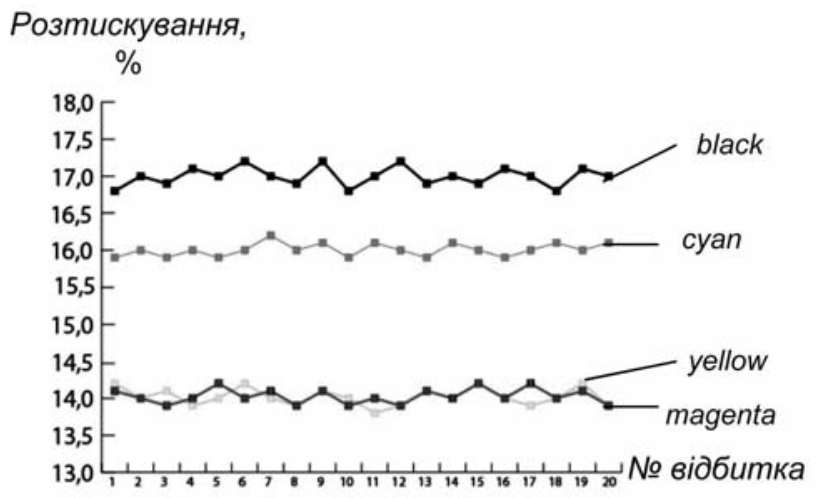

Рис. 6. Розтискування крапки на офсетному папері Lumiset масою 1 м $^{2} 80$ г, поле $40 \%$ 


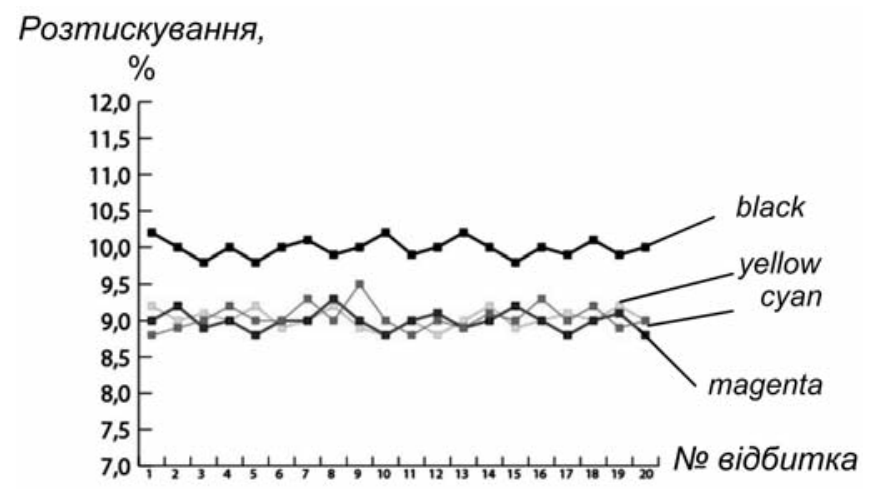

Рис. 7. Розтискування крапки на крейдованому глянцевому папері N

Blu Star Gloss масою 1 м² 120 г, поле 80 \%

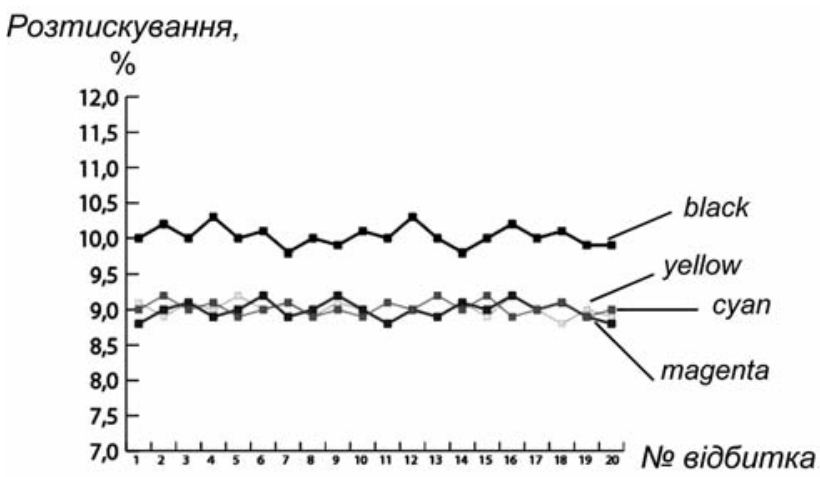

Рис. 8. Розтискування крапки на крейдованому матовому папері

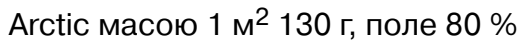

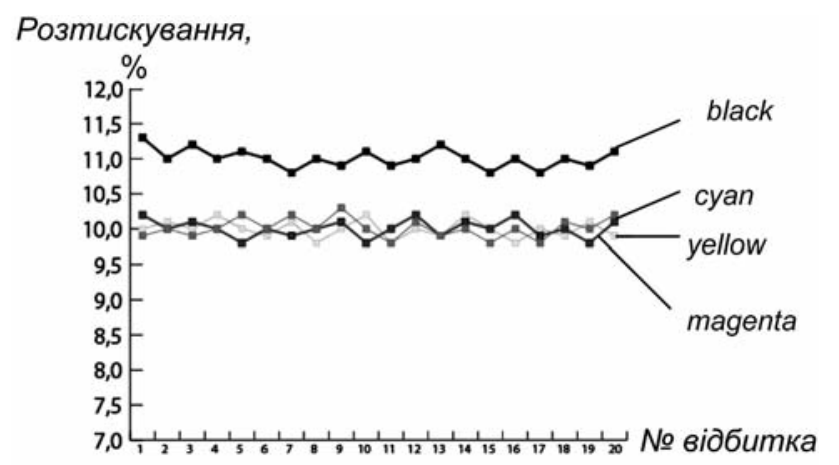

Рис. 9. Розтискування крапки на офсетному папері Lumiset масою 1 м $^{2} 80$ г, поле $80 \%$ 
покриття 40 \% і 80 \% шкали оперативного контролю, отриманих при друкуванні на різних видах паперу.

Для підтвердження результати вимірювань статистично оброблялися: розрахунок середнього значення оптичної густини (проводився за формулою (1)), розрахунок стандартного відхилення (проводився за формулою (2)), розрахунок розкиду (за формулою (3)) [9-11].

Дані розрахунків наведено в табл. 2.

Результати проведених досліджень дозволяють проаналізувати вплив комплексного технологічного процесу обробки друкарського циліндра в парі з противідмарювальною металевою пластиною, на розтискування крапки зокрема та якості відбитка загалом. Отримані результати вимірювання розтискування крапки хоч і різняться між собою, але перебувають в межах норм. Якщо порівнювати зі стандартом ISO 12647.2-2004 суттєвих відмінностей не спостерігається, а стандартні відхилення порівняно з нормованими перебувають у межах 0,9-5 \% (згідно зі стандартом максимальне відхилення між приростом растрової крапки (розтискування) на кольоропробі і еталонному відбитку може досягати 7 \%), процентне відношення розкиду до стандартних відхилень становить 1-7 \%, що не виходить за допустимі межі.

\section{Висновки}

Результати досліджень параметрів якості відбитка, свідчать про високий рівень показників і стабільність процесу друкування, що пояснюється прямою залежністю між комплексним технологічним процесом та параметрами якості поліграфічної продукції.

Отримані результати параметрів якості відбитка, а саме показники оптичної густини у процентному співвідношенні до нормативних показників, перебувають в інтервалі від 0,3 \% до $4 \%$, процентне співвідношення розкиду до середніх значень - від 1,4 \% до 3 \%; показники розтискування крапки порівняно з нормованими знаходяться у межах 0,9-3 \%.

$€$ очевидним доцільність застосування оздоблювальнозміцнювальної обробки методом вібраційного накатування з подальшим хромуванням, яка підвищує експлуатаційні властивості за рахунок утворення регулярного мікрорельєфу 3 хромуванням поверхні друкарського циліндра з одного боку та утримує показники якості відбитка в межах стандартизованих величин з іншого.

\section{Список використаної літератури}

1. Технология печатных процессов / под ред. А. Н. Раскина. - М. : Книга, 1989. - 432 с.

2. Киричок П. О., Величко О. М., Гавенко С. Ф. та ін. Український тлумачний словник видавничо-поліграфічної справи / за заг. ред. П. О. Киричка. - Київ : НТУУ «КПІ», 2011. - 896 с.

3. Мельников О. В. Друкування на аркушевих офсетних машинах. Львів : Афіша, 1999. - 160 с. 
Таблиця 2

Математично-статистичні розрахунки показників оптичної густини

\begin{tabular}{|c|c|c|c|c|c|}
\hline \multirow[b]{2}{*}{ Фарба } & \multicolumn{5}{|c|}{ Розтискування крапки } \\
\hline & $\begin{array}{c}\text { Середнє } \\
\text { значення, } \\
\bar{X}\end{array}$ & $\begin{array}{c}\text { Стандартне } \\
\text { відхилення, } \\
\mathrm{S}\end{array}$ & $\begin{array}{c}\text { Розкид, } \\
\text { R }\end{array}$ & \begin{tabular}{|c|} 
Відношення \\
стандартного \\
відхилення до \\
нормованого \\
показника
\end{tabular} & $\begin{array}{c}\text { Відношення } \\
\text { розкиду до } \\
\text { стандартного } \\
\text { показника }\end{array}$ \\
\hline \multicolumn{6}{|c|}{ Папір Blu Star Gloss масою 1 м² 120 г, поле 40 \% } \\
\hline Cyan & 14 & 0,24 & 0,9 & 1,7 & 6,4 \\
\hline Magenta & 12,1 & 0,3 & 1,2 & 2,5 & 9,9 \\
\hline Yellow & 12,0 & 0,18 & 0,7 & 1,5 & 5,8 \\
\hline Black & 14,03 & 0,15 & 0,55 & 1,07 & 3,9 \\
\hline \multicolumn{6}{|c|}{ Папір Blu Star Gloss масою 1 м² 120 г, поле 80 \% } \\
\hline Cyan & 9,0 & 0,18 & 0,7 & 2 & 7,7 \\
\hline Magenta & 9,0 & 0,14 & 0,4 & 1,5 & 4,4 \\
\hline Yellow & 9,0 & 0,13 & 0,4 & 1,4 & 4,4 \\
\hline Black & 9,9 & 0,15 & 0,4 & 1,5 & 4,0 \\
\hline \multicolumn{6}{|c|}{ Папір Arctic масою 1 м $^{2} 130$ г, поле $40 \%$} \\
\hline Cyan & 15,0 & 0,12 & 0,4 & 0,8 & 2,7 \\
\hline Magenta & 12,0 & 0,12 & 0,4 & 1,0 & 3,3 \\
\hline Yellow & 11,9 & 0,11 & 0,4 & 0,9 & 3,4 \\
\hline Black & 14,0 & 0,12 & 0,4 & 0,85 & 2,8 \\
\hline \multicolumn{6}{|c|}{ Папір Arctic масою 1 м² 130 г, поле $80 \%$} \\
\hline Cyan & 9,0 & 0,1 & 0,3 & 3,3 & 1,1 \\
\hline Magenta & 8,9 & 0,11 & 0,4 & 4,0 & 1,2 \\
\hline Yellow & 9 & 0,12 & 0,4 & 4,0 & 1,3 \\
\hline Black & 10,03 & 0,09 & 0,5 & 5 & 0,9 \\
\hline \multicolumn{6}{|c|}{ Папір Lumiset масою 1 м² 80 г, поле 40 \% } \\
\hline Cyan & 16 & 0,09 & 0,3 & 0,6 & 1,9 \\
\hline Magenta & 14,0 & 0,11 & 0,3 & 0,8 & 2,1 \\
\hline Yellow & 14,0 & 0,12 & 0,4 & 0,86 & 2,8 \\
\hline Black & 17,0 & 0,13 & 0,4 & 0,8 & 2,3 \\
\hline \multicolumn{6}{|c|}{ Папір Lumiset масою 1 м² 80 г, поле 80 \% } \\
\hline Cyan & 10,0 & 0,11 & 0,4 & 1,1 & 4 \\
\hline Magenta & 10,0 & 0,13 & 0,4 & 1,3 & 4 \\
\hline Yellow & 10,0 & 0,13 & 0,4 & 1,3 & 4 \\
\hline Black & 11,0 & 0,12 & 0,5 & 1,09 & 4,5 \\
\hline
\end{tabular}


4. Величко О. М. Опрацювання інформаційного потоку взаємодією елементів друкарського контакту : монографія. - Київ : Видав.-полігр. центр «Київський університет», 2005. - 264 с.

5. Гавенко С. Ф., Мельников О. В. Стандарти у видавничо-поліграфічній галузі : навч. посіб. Львів : УАД, 2006. -132 с.

6. Мельников О. В. Технологія плоского офсетного друку / за ред. д-ра техн. наук, проф. Е. Т. Лазаренка. - 2-ге вид., виправл. - Львів : УАД, 2007. $388 \mathrm{c}$.

7. Волков П. Н., Галкин С. М., Добин Л. М., Якименко Ю. И. Ремонт полиграфического оборудования. - М. : Книга, 1982. - 261 с.

8. Шнейдер Ю. Г. Технология финишной обработки давлением : справочник. - СПб. : Политехника, 1998. - 414 с.

9. Назар І. М., Лазаренко Е. Т., Якуцевич С. Параметри відбитків рулонного офсетного друку : фактори управління і впливу : монографія. Львів : УАД, 2009. - 128 с.

10. Либерман Н. И. Статистические методы контроля качества печатной продукции. - М. : Книга, 1977. - 289 с.

11. Якуцевич С., Мервинский Р. Управление качеством в полиграфии статистическими методами // Технологія і техніка друкарства. - 2005. № 2. - С. 16-26. - Режим доступу : http://druk.kpi.ua/node/538.

\section{References}

1. (1989). Tehnologiya pechatnyih protsessov [Technology of printing processes]. Moscow: Knyha [in Russian].

2. Kyrychok, P. O. \& Velychko, O. M. \& Havenko, S. F. \& Zorenko, O. V. \& Kyrychok, T. Yu. \& Rozum, T. V. (2011). Ukrainskyi tlumachnyi slovnyk vydavnycho-polihrafichnoi spravy [Ukrainian glossary of publishing and printing]. Kyiv: NTUU 'KPI' [in Ukrainian].

3. Melnykov, O. V. (1999). Drukuvannia na arkushevykh ofsetnykh mashinakh [Printing on sheet offset machines]. Lviv: Afisha [in Ukrainian].

4. Velychko, O. M. (2005). Opratsiuvannia informatsiinoho potoku vzaiemodiieiu elementiv drukarskoho kontaktu [Processing information flow of elements of contact printing]. Kyiv: Vydav.-polihr. tsentr 'Kyyivskyi universytet' [in Ukrainian].

5. Havenko, S. F. \& Melnykov, O. V. (2006). Standarty u vydavnycho-polihrafichnii haluzi [Standards in the publishing and printing industry]. Lviv: UAD [in Ukrainian].

6. Melnykov, O. V. (2007). Tekhnolohiia ploskoho ofsetnoho druku [Flat offset printing technology]. Lviv: UAD [in Ukrainian].

7. Volkov, P. N. \& Halkyn, S. M. \& Dobin, L. M. \& Yakymenko, Yu. Y. (1982). Remont polygraficheskogo oborudovaniya [Repair of printing equipment]. Moscow: Knyha [in Russian].

8. Shneyder, Yu. H. (1998). Tekhnologiya fynyshnoi obrabotks davleniem [Finishing process for pressure]. Sankt-Peterburg: Politekhnika [in Russian].

9. Nazar, I. M. \& Lazarenko, E. T. \& Yakutsevych, S. (2009). Parametry vidbytkiv rulonnoho ofsetnoho druku: faktory upravlinnia i vplyvu [Options of imprints of web offset printing, management and impact factors]. Lviv: UAD [in Ukrainian]. 
10. Liberman, N. Y. (1977). Statisticheskie metody kontrolya kachestva pechatnoi produktsii [Statistical methods of quality control of printed products]. Moscow: Knyha [in Russian].

11. Yakutsevich, S. \& Mervinskiy, R. (2005). Upravlenie kachestvom v polygrafii statisticheskimi metodami [Quality of management in polyhraphy by statistic methods]. Journal of Tekhnolohiia i tekhnika drukarstva - Technology and Technique of Typography, 2, 16-26. Retrieved from http:// http://druk.kpi.ua/ node/538 [in Russian].

Исследованы параметры качества печатного оттиска при двухсторонней печати на листовых офсетных машинах. Установлена взаимосвязь между обработкой поверхности печатного цилиндра и параметрами качества печатного оттиска.

Ключевые слова: офсетная листовая машина; двухсторонняя печать; печатный цилиндр; отделочно-укрепляющая обработка; оптическая плотность; растискивание точки.

The quality parameters of printed impressions obtained via duplex printing on a sheet-fed offset press were studied in the article. The efficiency improvement of a sheet-fed offset press is achieved by using turning pages devices. The quality of a printed impression is affected by many factors, one of which is the duplex printing press construction, such as printing cylinder, on which, when turning, a metal plate is mounted to protect the printed image. Disability and accelerated failure during operation are the result of processes that occur in the surface layers. Thus the analysis of the research of the printed impressions' parameters is relevant considering the application of the finishing-strengthening treatment by rolling vibration and the followed chrome coverage of an impression cylinder, which increases the performance properties due to the formation of a regular microrelief of the chrome surface of an impression cylinder and maintaining the quality of a printed impression within the standardized values.

Keywords: sheet offset machine; duplex printing; printing cylinder; finishing-strengthening treatment; optical density; dot gain. 